some indication of their presence. This year I ascertained the positions of several of these showers with great care. The number of meteors from them averaged from 3 to 5 only, but the paths intersect nearly at a point in the individual cases, so that the centres are entitled to the same value as positions resulting from a large number of tracks. I give the best of these co-Lyrid showe:s, and the nearest confirmations from previous observations :-

Observed
1885 $\quad \begin{gathered}\text { Previous } \\ \text { Observations }\end{gathered}$ Authority

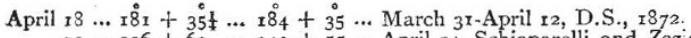

$19 \ldots 236+62 \ldots 240+55 \ldots$ April 14 , Schiaparelli and Zezioli.

$20 \ldots 226+41 \quad \ldots 223+40 \ldots$ March 12 -April 30 , Greg and Herschel.

${ }_{18} 80 \ldots 296 \pm 0 \quad \ldots 294 \pm$ o... April 16-19, 1877, D.

$19-20 \ldots 230+{ }_{1} \ldots 230+26 \ldots$ April $20-24$, Heis.

$18.20 \ldots 299+24 \ldots\left\{\begin{array}{l}298+25 \ldots \text { April } 16-19,1877, D . \\ 300+20 \ldots \text { April-May, Corder. }\end{array}\right.$

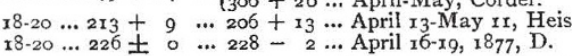

The two radiants observed here in 1877 and $\mathrm{I} 885$, with mean position at $295^{\circ} \pm 0^{\circ}$ and $298^{\circ} \cdot 5+24^{\circ} \cdot 5$, are very interesting. The former, just preceding $\eta$ Aquilæ on the equator, supplies meteors of very great velocity, the latter in Vulpecula gives swift, streak-leaving meteors. This pair of showers, directed from points near the apex of the earth's way, are now, I believe, very exactly determined in regard to their centres of radiation. That they have hitherto evaded frequent detection is not surprising, as they only become well visible in the morning hours. It will be useful to watch for these special streams during future exhibitions of the Lyrids, as well as to note the several other interesting features closely associated with this well-known display.

W. F. DENNING

\section{Chinese Insect Wax}

THE beetle alluded to in connection with this subject in the last number of NATURE (vol. xxxi, p. 6i5) is a probably undescribed species of Brachytarsus, a genus of the family Anthribida, allied to the Curculionida. Through the courtesy of the authorities at Kew I have had specimens before me. The idea that it acts as a sort of midwife to assist at the birth of infant Coccidie is quite erroneous. The genus Brachytursus is a true parasite on Coccus, and its habits, in this connection, in Europe, have long been known. It is of course interesting to find " unity of habit" prevailing in the case of Coccus Pe-la, even to its parasite; but with regard to the latter there is nothing new ; some points in the general economy of the wax insect, in the notes published, are of far greater importance.

Lewisham, May I

R. MCLACHLAN

\section{The New Bird in Natal}

THERE can be little doubt from the description given by $\mathrm{Mr}$. Turnbull in your issue of April 16 (p. 554) that the bird lately obtained by him in Natal is the Standard-winged Nightjar, Cosmetornis (seu Macrodipteryx) vexillarius, Gould. It has not been met with in Cape Colony, which accounts for Mr. Turnbull's inability to find mention of it in Layard's " Birds of South Africa;" but in Mr. Sharpe's new edition of Layard's work (which Mr. Turnbull would do well to procure) he will find an account of this bird given at p. 89. It appears to have a wide geographical range, being found both on the west and east coasts of Africa; in Angola and Damaraland, in Natal, on the Zambesi (where 300 miles up the river Dr. Kirk found it quite common), in the islands of Bourbon and Madagascar, along the Red Sea shore, and on the island of Socotra. With this extended range it is somewhat remarkable that it has not yet been met with in Cape Colony. According to the observations of Dr. Kirk the singular prolongations of the primaries are peculiar to the males, and a seasonal peculiarity observed only during the months from October until January. The habits of this bird, like those of other nightjars, are crepuscular. An excellent coloured figure of the male is given in Gould's "I Icones Avium."

\section{J. E. Harting}

\section{Wild Bees}

A FEW words respecting a colony of wild bees (a species of Andrena) which I have just discovered in our garden, may interest your entomological readers. A day or two ago, on walking beside a low-turfed mound which supports two trees on one of our towns, I noticed that the grassy surface on the south - therefore the sunny-side was covered with little hillocks of earth, such as ants throw up after rain. On examination each little heap showed the circular hole which denotes a bee's nest, and the bees themselves were seen in many places going in and out. Some holes were level with the ground, but most had the tiny mound of soil cast up in the process of excavation. The peculiarity of the case seems to me to lie in the great number of nests forming a complete colony. It is difficult to count them, but there cannot be less than eighty or ninety in an arearoughiy calculated -of about sixty square feet. Have any of your readers noticed a similar city of these busy people? and can any one supply the specific name?

Further Barton, Cirencester, May 2

ON M. WOLF'S MODIFICATION OF FOUCAULTS APPARATUS FOR THE MEASUREMENT OF THE VELOCITY OF LIGHT

$\mathrm{N} O$ one who has the true interests of scientific accuracy at heart can fail to welcome any innovation whereby the elements of a research may be varied, for thereby the ever-lurking constant error is most readily eliminated. It seems, therefore, that this in itself is sufficient reason for the interesting paper communicated by M. Wolf to the Académie des Sciences (Comptes Rendus, 9 Février), describing a very ingenious arrangement of Foucault's experiment, and that there was no occasion for disparaging other work in order to justify its publication. It is to be hoped that this was done rather through inadvertence than design, but I feel called upon to correct some of the misapprehensions under which the author labours, and particularly those concerning the appearance and distinctions of the image of the slit in my work on the velocity of light.

M. Wolf remarks that, under the conditions which I selected, this image, even under the most favourable circumstances, must be bordered with very large diffraction fringes, which the atmospheric disturbances transform into a badly-defined "tache lumineuse." In reply to this, though I grant that the fringes ought to be present, yet I can affirm as a matter of fact that they were not to be seen. Possibly M. Wolf and others may have been somewhat misled by a drawing of the appearance of the image given in my work (p. I 24, Astr. Papers, American Ephemeris, and Nautical Almanac, vol. i. Part 3) where the image proper, which is quite clear, is surrounded by a luminous haze, from which, however, it is very easily distinguished.

I hardly think that if M. Wolf had given the "specimen observations" (p. 133 of my work) due consideration, he would have characterised as a "tache lumineuse" an image whose position was measured with the following results (each result is the mean of ten observations made by one observer, and recorded without divulging the result by another) :-

$$
\begin{aligned}
& \text { No. I } \ldots \quad \text { II } 2.801 \mathrm{~mm} . \quad \ldots \quad 0.020 \mathrm{~mm} \text {. } \\
& \begin{array}{lllllllll}
, & 2 & \ldots & 112.773 & , & \ldots & 0.006 &
\end{array}
\end{aligned}
$$

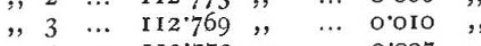

$$
\begin{aligned}
& \begin{array}{llllll}
, & 4 & \ldots & \text { II } 2.772,, & \ldots & 0.007,
\end{array} \\
& \text {, } 5 \ldots \text { I } 12.779,, \quad \ldots .0000 \\
& \text { Average difference from mean }=0.0086,
\end{aligned}
$$

These are measurements of the deflected image, so that the differences are not merely errors of linear measurement, but include errors in the estimate of the speed of the revolving mirror.

Now, M. Wolf, in his most sanguine statement, does not hope for a greater degree of accuracy than one part in 3500 in this particular measurement, whereas the above results are on the average closer than one part in Io,000.

But let us examine the data on which he bases this 